\title{
Evaluation of Single Root Canals Filled Using the Lateral Compaction, Tagger's Hybrid, Microseal and Guttaflow Techniques
}

\author{
Marina Angélica MARCIANO \\ Clovis Monteiro BRAMANTE \\ Marco Antonio Hungaro DUARTE \\ Ronan Jacques Rezende DELGADO \\ Ronald ORDINOLA-ZAPATA \\ Roberto Brandão GARCIA \\ Department of Operative Dentistry, Endodontics and Dental Materials, \\ Bauru Dental School, University of São Paulo, Bauru, SP, Brazil
}

\begin{abstract}
The aim of this study was to determine the percentage of voids, gutta-percha and root canal sealer using 4 different filling techniques. Fifty-two extracted maxillary lateral incisors were prepared using the crown-down pressureless technique. The teeth were randomly divided in 4 groups ( $\mathrm{n}=13$ ): Lateral compaction (LC), Tagger's hybrid (TH), MicroSeal (MS) and GuttaFlow (GF) techniques. Horizontal cross-sections were made at the 2,10 and $15 \mathrm{~mm}$ levels from the apex. Digital images of the root canal areas were acquired using a stereomicroscope and examined using the Image Tool 3.0 software. Statistical analysis was performed using the Kruskal-Wallis test $(\alpha=0.05)$. In general, a significant decrease in the gutta-percha filled area and increase of sealer area were observed at the apical level for all the evaluated techniques $(\mathrm{p}<0.05)$. With regard to the presence of voids, no significant difference was found. MS and TH techniques showed a larger gutta-percha filled area than LC and GF techniques at the coronal and middle third level $(\mathrm{p}<0.05)$. From the results of the present study, it may be concluded that the gutta-percha filled area of fillings decrease at the apical level, regardless of the filling technique used.
\end{abstract}

Key Words: gutta-percha, GuttaFlow, lateral compaction, Tagger's hybrid technique, endodontic treatment.

\section{INTRODUCTION}

Gutta-percha and sealer are frequently used during conventional root canal filling procedures. It has been reported that some sealers shrink upon setting whilst others are susceptible to dissolution in contact with tissue fluids (1). The root canal filling should provide the maximum possible amount of gutta-percha with minimal amount of sealer (2). There are several techniques to fill the root canals, all of them claiming to offer a tridimensional seal with a low degree of toxicity to the periapical tissues.

Callahan (3) proposed the cold lateral compaction technique, which involves placing auxiliary gutta-percha points laterally to a master point sealed in the root canal. Lateral compaction is the obturation technique most widely taught in dental schools and used by practitioners, and it is still the standard to which all other techniques are compared.

Alternative techniques using thermal or frictional heat to plasticize the gutta-percha have been introduced, allowing for its better adaptation to canal walls with higher degree of homogeneity (4). In 1980, John T. McSpadden proposed the thermomechanical compaction technique (5). In this technique, the use of McSpadden's compactors produces friction between the gutta-percha and the internal walls of the root canal, leading to the thermoplastification of gutta-percha. Unfortunately, this procedure can produce the extrusion of filling material toward the apical third. In order to avoid this problem, Tagger (6) proposed a hybrid technique wherein thermomechanical compaction is used after the lateral

Correspondence: Dra. Marina Angélica Marciano, Faculdade de Odontologia de Bauru, USP, Alameda Octávio Pinheiro Brisolla, 9-75, 17012-901 Bauru, SP, Brasil. e-mail: marinangelica@usp.br 
compaction of the apical third of the root canal.

Another technique of thermoplastification of gutta-percha is the MicroSeal System (Analytic, Glendora, CA, USA). This technique uses a master guttapercha point (MicroFlow, Analytic) and heated guttapercha placed in cartridges inserted into the root canal using a syringe (7). In 2004, Coltène/Whaledent Inc. (Cuyahoga Falls, Altstatten, Switzerland) introduced a cold, flowable, self-curing filling material for root canals that combine gutta-percha and sealer into one injectable system (GuttaFlow). The sealer contains gutta-percha in particle form combined with a polydimethylsiloxanebased sealer (8) GuttaFlow has shown good adaptability to root canal walls (9). However, there are few studies comparing GuttaFlow with other techniques with regard to the contents of filling, measuring the gutta-percha filled area.

The purpose of this study was to evaluate the root canal filling measuring the percentage of guttapercha, sealer and voids using the lateral compaction, the Tagger's hybrid, MicroSeal and GuttaFlow techniques.

\section{MATERIAL AND METHODS}

Fifty-two maxillary lateral incisors with single straight canals that had anatomical diameter corresponding to a size $20 \mathrm{~K}$ file were selected for this study. The teeth were randomly divided into 4 groups according to the filling technique $(n=13)$ : Lateral Compaction, Tagger's hybrid, MicroSeal and GuttaFlow.

Conventional pulp chamber access was performed using high-speed burs. The root canal length was determined by introducing a size $15 \mathrm{~K}$ file until it was visible at the apex. The working length was determined by subtracting $1 \mathrm{~mm}$ from the total root canal length. The root canals were cleaned and shaped using the crown-down pressureless technique (10). Gates Glidden burs were used in the middle and coronal thirds and $\mathrm{K}$ files were used in a crown down pressureless sequence until the apical diameter of a size $40 \mathrm{~K}$ file was reached. During the instrumentation procedures, $2 \mathrm{~mL}$ of $2 \%$ $\mathrm{NaOCl}$ solution was used before each file. All specimens received a final flush of $2 \mathrm{~mL}$ of $17 \%$ EDTA for $3 \mathrm{~min}$ and $5 \mathrm{~mL}$ of saline solution. Then, the root canals were dried with sterile paper points and obturated by the same operator, following manufacturer's instructions. Sealer 26 (Dentsply Ind. e Com. Ltda., Petrópolis, RJ, Brazil) was used, except for the GuttaFlow group.

Lateral Compaction Group: A size 40 master gutta-percha point (Dentsply Maillefer, Ballaigues, Switzerland) was fitted at the working length. The root canals were filled with the $\mathrm{LC}$ technique using a size $\mathrm{B}$ endodontic finger spreader (Dentsply Maillefer) inserted 2-3 $\mathrm{mm}$ short of the working length, and 7-10 accessory gutta-percha points size 20 with .02 taper (Dentsply Maillefer) were used until the entire length of the root canal was filled.

Tagger's hybrid Group: A size 40 master guttapercha point (Dentsply Maillefer) was introduced into the root canal at the working length. Lateral compaction was performed using a spreader and 4 auxiliary guttapercha points (Dentsply Maillefer) to obturate the apical $5 \mathrm{~mm}$ of the root canal. Thermomechanical compaction was performed with a size 45 gutta-percha stainless compactor (Gutta condenser; Dentsply Maillefer). Rotation of the compactor was started at $8,000 \mathrm{rpm}$. The plugger was carried apically up to $5 \mathrm{~mm}$ from the apical stop and slowly removed. After approximately $2 \mathrm{~s}$, the compactor was removed slowly whilst being pushed softly against one side of the canal.

MicroSeal Group: Root canals were filled using a modified technique of the MicroSeal system (Analytic) (7). The first step of the procedure was the selection of the size 40 master gutta-percha point (Dentsply Maillefer) and its adjustment to achieve tug-back, 0.5 to $1 \mathrm{~mm}$ short of the working length. The sealer was placed into the canal with the master point and the sealer-coated master gutta-percha point was seated. A size B endodontic finger spreader (Dentsply Maillefer) was inserted along the master point at the appropriate length for compaction. Initial lateral compaction was done with two size 20, .02 taper accessory points (Dentsply Maillefer). The spreader was reinserted and an appropriate nickeltitanium compactor was coated with a uniform layer of material of the heated gutta-percha cartridge (Analytic) based on the manufacturer's instruction. A coated guttapercha compactor was then carried immediately to the void previously created in the canal by the spreader and placed as close to the working length as possible. With the application of a resisting force to the compactor's backing-out motion but without any apical pressure, the rotation of the compactor began at a speed of 5,000 rpm (7). After approximately $2 \mathrm{~s}$, the compactor was removed slowly whilst being pushed softly against one side of the canal. Rotation did not stop until the compactor was removed from the canal. Mild pressure was then applied in apical direction (vertical compaction) with a hand plugger, followed by a reinsertion of the spreader. If the 
first step did not fill the canal completely, the compactor was coated with a further increment of alpha-phase gutta-percha and the procedure repeated.

GuttaFlow Group: The activated capsule was mixed for $30 \mathrm{~s}$ in a triturator. The tip of the GuttaFlow device was introduced into the root canal $3 \mathrm{~mm}$ short of the working length, and GuttaFlow was inserted. The size 40 master gutta-percha point (Dentsply Maillefer) was coated with GuttaFlow and inserted to the working length. By pressing the master gutta-percha point laterally, the tip of the device was inserted again into

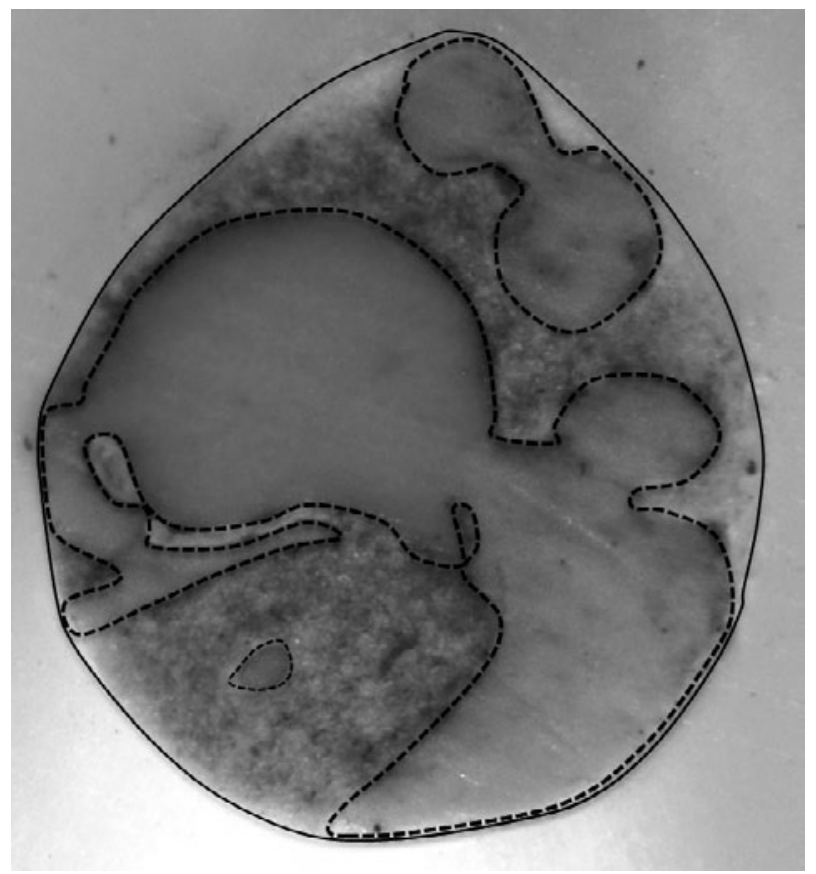

Figure 1. Representative section of the Tagger's hybrid technique at the middle third. The canal area is delimited by the continuous line and the gutta-percha area by the dotted line. the canal to seal the backfill space.

Excess of gutta-percha was removed by using a heated plugger. Vertical compaction was performed with a hand plugger at the level of the root canal orifice for all groups. The specimens were kept for $72 \mathrm{~h}$ at $37^{\circ} \mathrm{C}$ and $100 \%$ humidity to allow the sealers to set completely. Three horizontal sections were made at 2 , 10 and $15 \mathrm{~mm}$ levels from the anatomical apex using a $0.3 \mathrm{~mm}$ Isomet saw (Buehler, Lake Bluff, IL, USA) totalizing 156 sections of 52 teeth. Then, digital images of the sections were acquired using a stereomicroscope Leica MZ6 (Leica Microsystems, Wetzlar, Germany). Image analysis and measurements were performed by using Image Tool 3.0 (UTHSCSA, TX, USA), through outlined of the area, in $\mathrm{mm} 2$, corresponding to the root canal, sealer and gutta-percha (Fig. 1). Statistical analysis was done by the non-parametric Kruskal-Wallis and Miller tests $(\alpha=0.05)$.

\section{RESULTS}

No significant differences ( $\mathrm{p}>0.05)$ were found between the total areas of the apical third for techniques. The mean percentage areas of gutta-percha, sealer and voids are shown in Tables 1-3. In all groups, at the apical level, it was observed a decreased of the percentage area of gutta-percha and an increase of sealer, with significant difference $(p<0.05)$ among the groups. The percentage of voids area was significantly inferior $(p<0.05)$ in comparison to the sealer area in the apical third. At this same level, considering the presence of voids, there was no significant difference $(\mathrm{p}>0.05)$ among the techniques.

MicroSeal and Tagger's Hybrid showed higher percentage of gutta-percha at the coronal and middle thirds than GuttaFlow and lateral compaction. The GuttaFlow technique showed an increment of voids at the coronal third in comparison to the other groups $(\mathrm{p}<0.05)$. It was not observed significant difference among the groups considering the gutta-percha mean percentage area at the apical level.

\section{DISCUSSION}

The goal of the endodontic treatment is to clean, shape and fill the root
LC=Lateral compaction; TH=Tagger's hybrid; MS=Microseal; GF=GuttaFlow. Different letter in each line indicate statistically significant differences $(p<0.05)$. 
canal space thoroughly to prevent apical or coronal leakage (4). Many obturation techniques have been developed to obtain a complete root canal filling. For comparative purposes, the composition of the root filling techniques have been evaluated by achieving the percentage area of gutta-percha, sealer and voids $(11,12)$. In the present study, lateral incisors were used in attempt to avoid the presence of isthmus or flattening areas, commonly found in molars and mandibular incisors (13). Moreover, the teeth selected for this study had anatomical diameter corresponding to a size $20 \mathrm{~K}$ file, with the aim of standardizing the diameter of the apical stop in the samples (14).

In agreement with previous results (15), the present study showed that, in general, the percentage of gutta-percha-filled area decreased at the apical level. Better results in the gutta-percha filled area at the apical level could be expected by increasing the apical diameter of root canal preparation $(12,16)$. At the coronal and middle level of the canal, the adaptation of the filling material was found to be easier because of the ability of finger spreader and compactors to access this area.

Table 2. Mean percentage (\%) of gutta-percha, sealer and voids at the $10 \mathrm{~mm}$ level.

\begin{tabular}{lcccc}
\hline & LC & TH & MS & GF \\
\hline $\begin{array}{l}\text { Gutta-percha } \\
\text { area (\%) }\end{array}$ & $72.61 \pm 6.62^{\mathrm{ab}}$ & $74.71 \pm 15.02^{\mathrm{ab}}$ & $79.11 \pm 23.20^{\mathrm{a}}$ & $64.97 \pm 9.96^{\mathrm{b}}$ \\
Sealer area (\%) & $25.98 \pm 7.28^{\mathrm{a}}$ & $23.39 \pm 13.64^{\mathrm{ab}}$ & $14.40 \pm 8.96^{\mathrm{b}}$ & $30.32 \pm 10.30^{\mathrm{a}}$ \\
& $1.01 \pm 2.12^{\mathrm{a}}$ & $1.89 \pm 3.10^{\mathrm{a}}$ & $0.52 \pm 1.31^{\mathrm{a}}$ & $4.71 \pm 3.00^{\mathrm{b}}$ \\
Voids (\%) & & & & \\
\hline
\end{tabular}

LC=Lateral compaction; TH=Tagger's hybrid; MS=Microseal; GF=GuttaFlow. Different letter in each line indicate statistically significant differences $(\mathrm{p}<0.05)$.

Table 3. Mean percentage (\%) of gutta-percha, sealer and voids at the $15 \mathrm{~mm}$ level.

\begin{tabular}{lcccc}
\hline & LC & TH & MS & GF \\
\hline $\begin{array}{l}\text { Gutta-percha } \\
\text { area (\%) }\end{array}$ & $69.63 \pm 14.93^{\mathrm{ac}}$ & $93.61 \pm 2.60^{\mathrm{b}}$ & $88.33 \pm 10.24^{\mathrm{ab}}$ & $42.39 \pm 16.87^{\mathrm{c}}$ \\
Sealer area (\%) & $29.71 \pm 14.71^{\mathrm{ac}}$ & $6.22 \pm 2.47^{\mathrm{b}}$ & $10.99 \pm 9.86^{\mathrm{ab}}$ & $54.20 \pm 18.50^{\mathrm{c}}$ \\
& $0.66 \pm 0.78^{\mathrm{a}}$ & $0.43 \pm 1.03^{\mathrm{a}}$ & $0.46 \pm 1.18^{\mathrm{a}}$ & $6.73 \pm 4.80^{\mathrm{b}}$ \\
Voids (\%) & & & & \\
\hline
\end{tabular}

LC=Lateral compaction; TH=Tagger's hybrid; MS=Microseal; GF=GuttaFlow. Different letter in each line indicate statistically significant differences $(\mathrm{p}<0.05)$. percentage of voids and volume of searer in compa percentage of voids and volume of sealerin companison the the ther groups especially at the middle and coronal . This fact may be explained by the use of a single cone to fill the root canals based on manufacturer instructions, with the consequent absence of compaction of the material against the root canal walls. This study showed that the probability to form gaps increases when the single cone technique is used, as shown by Hammad et al. (17). Thus, the use of accessory points should be recommended for filling the middle and coronal thirds when using GuttaFlow technique.

As shown by previous studies, there is a relationship between the presence of voids and the filling technique used $(11,18,19)$. In general, thermoplastification techniques, such as MicroSeal and Tagger's hybrid, show a higher percentage of guttapercha than GuttaFlow and lateral compaction techniques at the coronal and middle thirds. In this study, the lateral compaction group showed lower gutta-percha filled area in comparison to the results found by Souza et al. (2), in which the canals were instrumented until the diameter of a $50 \mathrm{~K}$ file. Probably, the difference in these results can be related to the variation in the apical enlargement. By using the lateral compaction technique, the inner surface of the prepared root canal cannot be replicated and is usually filled by the sealer at the middle and cervical thirds.

In conclusion, the evaluated root canal filling techniques showed similar gutta-percha and sealer areas in the apical third. MicroSeal and Tagger hybrid techniques resulted in the greatest performance in the middle and cervical thirds, considering that minimal sealer and increased guttapercha area are high-quality measures. GuttaFlow group, on the other hand, showed an excessive presence of voids at the same levels. 


\section{RESUMO}

O objetivo do estudo foi determinar a porcentagem de espaços vazios, guta-percha e cimento após a obturação por 4 diferentes técnicas. Cinquenta e dois incisivos laterais superiores humanos extraídos foram instrumentados pela técnica coroa-ápice sem pressão. Os dentes foram randomicamente divididos em 4 grupos ( $\mathrm{n}=13)$ : Condensação lateral (LC), Técnica híbrida de Tagger (TH), MicroSeal (MS) e GuttaFlow (GF). Foram feitas secções horizontais a 2, 10 e $15 \mathrm{~mm}$ do ápice. Imagens digitais foram obtidas dos canais por meio de estereomicroscópio e analisadas no programa Image Tool 3.0. A análise estatística foi feita utilizando o teste de Kruskal-Wallis $(\alpha=0,05)$. Em geral foi observado um significante decréscimo na área de guta-percha e um aumento na área de cimento para todas as técnicas analisadas $(\mathrm{p}<0,05)$. Com relação à presença de espaços vazios, não houve diferença estatística entre as técnicas $(p>0,05)$. As técnicas MS e TH apresentaram área de guta-percha maior que as técnicas LC e GF nos terços médio e cervical $(\mathrm{p}<0,05)$. Após análise dos resultados foi possível concluir que a área de guta-percha nas obturações diminui em sentido apical, independente da técnica utilizada.

\section{ACKNOWLEDGEMENTS}

This work was supported by The São Paulo State Research Foundation - FAPESP (2008/00027-8).

\section{REFERENCES}

1. Kontakiotis EG, Wu MK, Wesselink PR. Effect of sealer thickness on long-term sealing ability: a 2-year follow-up study. Int Endod J 1997;30:307-312.

2. Souza EM, Wu MK, van der Sluis LW, Leonardo RT, Bonetti-Filho I, Wesselink PR. Effect of filling technique and root canal area on the percentage of gutta-percha in laterally compacted root fillings. Int Endod J 2009;42:719-726.

3. Callahan JR. Rosin solution for the sealing of the dentinal tubuli and as an adjuvant in the filling root-canals. Dent Cosmos 1914;56:1376.

4. Schilder H. Filling root canals in three dimensions. Dent Clin North Am 1967;11:723-744.

5. McSpadden J. Self study for the thermatic condensation of guttapercha. Toledo: Ransom and Randolph; 1980.
6. Tagger M, Tamse A, Katz A, Korzen BH. Evaluation of the apical seal produced by a hybrid root canal filling method, combining lateral condensation and thermatic compaction. J Endod 1984;10:299-303.

7. Gençoğlu N. Comparison of 6 different gutta-percha techniques (part II): Thermafil, JS Quick-Fill, Soft Core, Microseal, System $\mathrm{B}$, and lateral condensation. Oral Surg Oral Med Oral Pathol Oral Radiol and Endod 2003;96:91-95.

8. Zielinski TM, Baumgartner JC, Marshall JG. An evaluation of Guttaflow and gutta-percha in the filling of lateral grooves and depressions. J Endod 2008;34:295-298.

9. ElAyouti A, Achleithner C, Lost C, Weiger R. Homogeneity and adaptation of a new gutta-percha paste to root canal walls. J Endod 2005;31:687-690.

10. Morgan LF, Montgomery S. An evaluation of the crown-down pressureless technique. J Endod 1984;10:491-498.

11. Wu MK, Wesselink PR. A primary observation on the preparation and obturation of oval canals. Int Endod J 2001;34:137-141.

12. ElAyouti A, Kiefner P, Hecker H, Chu A, Lost C, Weiger R. Homogeneity and adaptation of endodontic fillings in root canals with enlarged apical preparation. Oral Surg Oral Med Oral Pathol Oral Rad and Endod 2009;108:141-146.

13. Mannocci F, Peru M, Sherriff M, Cook R, Pitt Ford TR. The isthmuses of the mesial root of mandibular molars: a microcomputed tomographic study. Int Endod J 2005;38:558-563.

14. Ingle JI, Bakland LK, Peters DL, Buchanan LS. Endodontic cavity preparation. In: Endodontics. Ingle JI, Bakland LK (Editors). 5th ed. Malvern: Williams \& Wilkins; 1994:92-228.

15. Romania C, Beltes P, Boutsioukis C, Dandakis C. Ex-vivo areametric analysis of root canal obturation using gutta-percha cones of different taper. Int Endod J 2009;42:491-498.

16. Van der Borden WG, Wesselink PR. Percentages of gutta-perchafilled canal area observed after increased apical enlargement. J Endod 2010;36:139-142.

17. Hammad M, Qualtrough A, Silikas N. Evaluation of root canal obturation: a three dimensional in vitro study. J Endod 2009;35:541-544.

18. De-Deus G, Maniglia-Ferreira CM, Gurgel-Filho ED, Paciornik S, Machado AC, Coutinho-Filho T. Comparison of the percentage of gutta-percha-filled area obtained by Thermafil and System B. Aust Endod J 2007;33:55-61.

19. Wu MK, van der Sluis LW, Wesselink PR. Comparison of mandibular premolars and canines with respect to their resistance to vertical root fracture. J Dent 2004;32:265-268.

Accepted September 9, 2010 